Article

\title{
Development of Highly Selective 1,2,3-Triazole- containing Peptidic Polo-like Kinase 1 Polo-box Domain-binding Inhibitors
}

\author{
Xue Zhi Zhao *(D), Kohei Tsuji, David Hymel and Terrence R. Burke Jr. * \\ Chemical Biology Laboratory, Center for Cancer Research, National Cancer Institute, National Institutes of \\ Health, Frederick, MD 21702, USA; kohei.tsuji@nih.gov (K.T.); hymel.david@gmail.com (D.H.) \\ * Correspondence: xuezhi.zhao@nih.gov (X.Z.Z.); burkete@nih.gov (T.R.B.J.); \\ Tel.: +1-301-846-5907 (X.Z.Z.); +1-301-846-5906 (T.R.B.J.)
}

Academic Editors: Henry Mosberg, Tomi Sawyer and Carrie Haskell-Luevano Received: 29 March 2019; Accepted: 14 April 2019; Published: 16 April 2019

\begin{abstract}
Members of the polo-like kinase (Plk) family of serine/threonine protein kinases play crucial roles in cell cycle regulation and proliferation. Of the five Plks (Plk1-5), Plk1 is recognized as an anticancer drug target. Plk1 contains multiple structural components that are important for its proper biological function. These include an $\mathrm{N}$-terminal catalytic domain and a C-terminal non-catalytic polo-box domain (PBD). The PBD binds to phosphothreonine (pT) and phosphoserine-containing sequences. Blocking PBD-dependent interactions offers a potential means of down-regulating Plk1 function that is distinct from targeting its ATP-binding site. Previously, we demonstrated by tethering alkylphenyl chains from the $N(\pi)$-position of the His residue in the 5-mer PLHSpT, that we were able to access a hydrophobic "cryptic" binding pocket on the surface of the PBD, and in so doing enhance binding affinities by approximately 1000-fold. More recently, we optimized these PBD-ligand interactions using an oxime ligation-based strategy. Herein, using azide-alkyne cycloaddition reactions, we explore new triazole-containing PBD-binding antagonists. Some of these ligands retain the high PBD-binding affinity of the parent peptide, while showing desirable enhanced selectivity for the PBD of Plk1 relative to the PBDs of Plk2 and Plk3.
\end{abstract}

Keywords: Plk1; selectivity; polo-box domain; peptide; triazole

\section{Introduction}

Members of the polo-like kinase (Plk) family play crucial roles in mammalian cell cycle regulation and proliferation [1]. Proper function of Plks 1-4 requires the coordinated phosphorylation of serine and threonine residues by $\mathrm{N}$-terminal kinase domains (KDs) as well as engagement of protein-protein interactions (PPIs) with phosphoserine (pS)/phosphothreonine (pT)-containing sequences by means of their C-terminal polo-box domains (PBDs) [2]. While Plks 1-3 share significant homology, Plk4 is more distantly related $[3,4]$. The association of Plk1 over-expression with neoplastic transformation and tumor aggressiveness has defined it as a potentially promising anticancer molecular target [5-8]. To date, issues of collateral cytotoxicity have arisen for Plk1 kinase inhibitors. This is in part due to a lack of selectivity arising from the general homology among kinase catalytic domains. Given the uniqueness of PBDs to the Plk family, targeting PBD-mediated PPIs may allow down-regulation of Plk1 function with greater kinome selectivity than with inhibitors directed at the KD. However, Plk2 and Plk3 have roles in checkpoint-mediated cell-cycle arrest and maintenance of genetic stability, and they may serve as potential tumor suppressors $[3,4,9]$. Therefore, in developing PBD-binding inhibitors, it is desirable that they are selective for Plk1 versus Plk2 and Plk3. Because of the high homology among 
the PBDs of Plks 1-3, achieving selectivity for the PBD of Plk1 presents an important and challenging objective [7,8,10-13].

In designing Plk1 PBD-binding inhibitors, we have previously started with the polo-box interacting protein 1 (PBIP1)-derived 5-mer PLHSpT (1) (Figure 1) [7,14]. We found that up to 1000-fold enhancement of Plk1 PBD-binding affinity can be achieved by appending alkylphenyl groups from the His $N(\pi)$-position (as exemplified by 2a) [15]. A crystal structure of PBD-bound 2a revealed that the alkylphenyl group is situated within a hydrophobic aromatic box defined by residues Y417, Y421, Y481, L478, F482 and Y485. This may be considered as being "cryptic" in nature, since it is revealed by rotation of the Y481 side chain [15]. We have reached the pocket from parent 1 by a variety of approaches, including tethering alkylphenyl groups from the Pro residue [16], an amino-terminal $N$-alkyl Gly residue [17] and from macrocyclic variants [18,19]. The pocket can also be accessed from more extended peptides, such as the amino-terminal Phe residue of the PBIP1-derived peptide FDPPLHSpTA [20-22].
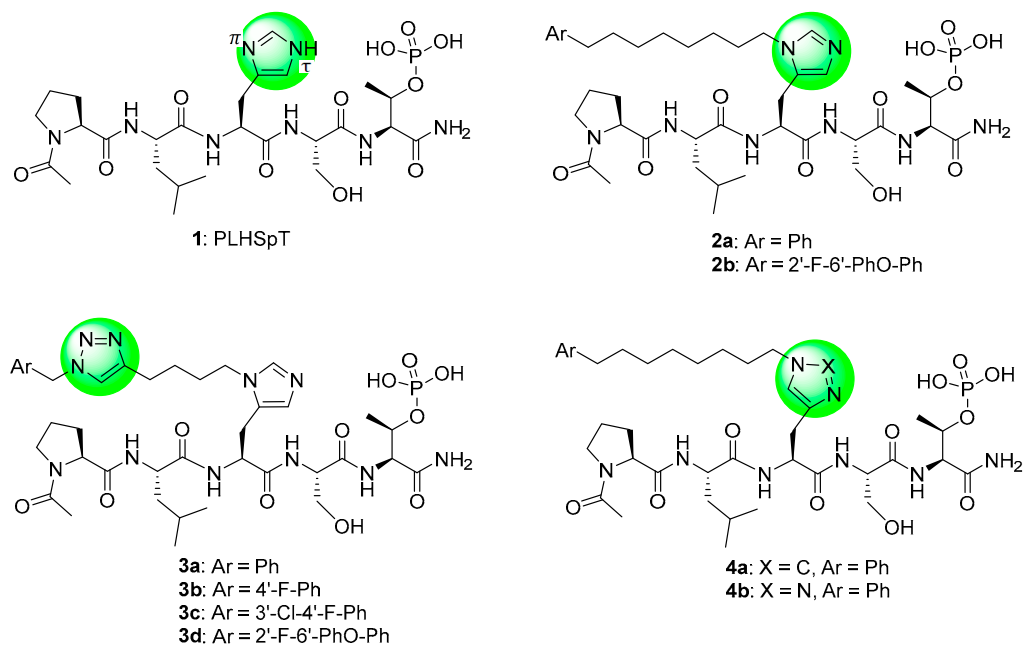

Figure 1. The polo-box interacting protein 1 (PBIP) pT78-derived peptide 1 and related derivatives discussed in the text.

The ability to engage the cryptic pocket has been a critical element of the highest affinity PBD-binding ligands reported to date. Within this context, the pT-2 position arguably represents the most efficient position from which to achieve this access, since it is the most proximal residue to the critical "SpT" recognition motif [23]. By examining a variety of non-proteinogenic amino acid residues at the pT-2 position, we found that the highest affinities were shown by those peptides having alkylation at the His- $N(\pi)$ position, which provided approximately 50 -fold higher affinity than alkylation at the isomeric His- $N(\tau)$ position (peptides $\mathbf{2 a}$ and $\mathbf{4 a}$, respectively, Figure 1) [24]. Yet, optimizing these interactions has been made difficult due to the tediousness of preparing individual His- $N(\pi)$-alkyl analogs. In response to these challenges, we employed an oxime-based post-solid phase peptide diversification strategy that allowed us to screen more than 80 analogs. Ligands such as $\mathbf{2 b}$ resulted, which show enhanced Plk1 PBD affinity or selectivity relative to parent 2a [25,26].

The utility of 1,2,3-triazoles for introducing conformational constraint in peptidomimetic chemistry has been reported [27-35]. A triazole replacement of the imidazole ring in His has been used to prepare constrained His mimics [36]. More recently, triazole-based His mimetics bearing long-chain alkylphenyl groups have been examined within the context of non-peptidic Plk1 PBD inhibitors [37]. However, the best of these constructs showed Plk1 PBD-binding affinities that were 5- to 18-fold less potent than $\mathbf{1}$ (which itself exhibits 3-orders of magnitude less affinity than 2a) [37]. Herein, we report the use of on-resin azide-alkyne cycloaddition reactions to introduce 1,2,3-triazole functionality into potent lead Plk1 PBD inhibitors based on $\mathbf{2 a}[15]$ and $\mathbf{2} \mathbf{b}[25,26]$. The triazole rings were intended either to induce conformational constraint (3a-3d) or to serve as a His mimetic (4b). This work has allowed 
us to prepare in facile fashion, new ligands that retain the high Plk1 PBD-binding affinity of the parent peptide, while enhancing selectivity for the PBD of Plk1 relative to the PBDs of Plk2 and Plk3.

\section{Results and Discussion}

\subsection{Synthesis}

Benzylazides $9 a-9 d$ were prepared using $S_{N} 2$ reactions of sodium azide with commercially available benzyl bromides $\mathbf{8 a}-\mathbf{8} \mathbf{c}$ and freshly prepared $\mathbf{8 d}$ (Scheme 1). Bromide $\mathbf{8} \mathbf{d}$ was synthesized in three steps from commercially available 2,6-difluorobenzylaldehyde (5). Displacement of one fluoro group in 5 by phenol afforded 6 [25], which was then reduced with sodium borohydride to yield alcohol 7. Application of the Appel reaction [38] using carbon tetrabromide and triphenylphosphine afforded bromide $\mathbf{8 d}$ (Scheme 1).

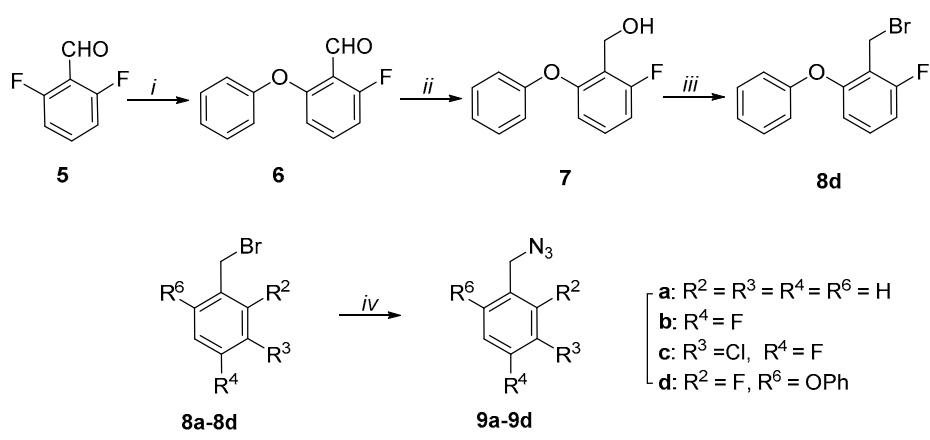

Scheme 1. Preparation of azides 9a-9d. Reagents and Conditions: i) $\mathrm{PhOH}, \mathrm{K}_{2} \mathrm{CO}_{3}$, dimethylacetamide (DMA), $165^{\circ} \mathrm{C}$; ii) $\mathrm{NaBH}_{4}, \mathrm{MeOH}$; iii) $\mathrm{CBr}_{4}, \mathrm{PPh}_{3}, \mathrm{CH}_{3} \mathrm{CN}$; iv) $\mathrm{NaN}_{3}$, acetone: $\mathrm{H}_{2} \mathrm{O}(5: 1)$.

The protected $N(\pi)$-alkyne-labeled His derivative $\mathbf{1 1}$ was easily obtained by alkylating $N^{\alpha}$-Fmoc$N^{\tau}$-Trt-L-His 2,4-dimethoxylbenzyl ester (10) [25] with hex-5-yn-1-ol according to our previously reported methodology [39]. This was then used to prepare the fully protected alkyne-containing peptide 12 on NovaSyn ${ }^{\circledR}$ TGR resin by standard Fmoc solid-phase peptide synthesis (SPPS) protocols in $\mathrm{N}$-methylpyrrolidone (NMP) (Scheme 2). Resin 12 was subsequently subjected to $\mathrm{Cu}(\mathrm{I})$ catalyzed $[3+2]$ cycloaddition reactions (on-resin CuAAC) with the related benzylazides 9a-9d (Scheme 2). The regioselective $\mathrm{CuAAC}$ reaction has been an important advance that provides a reliable means for selectively assembling 1,4-disubstituted 1,2,3-triazoles [40-42]. The resins were cleaved using a cocktail solution of TFA: $\mathrm{H}_{2} \mathrm{O}$ :triisopropylsilane (TIS) (95:2.5:2.5) to provide the triazole-containing peptides 3a-3d following HPLC purification. Alkyne-labeled peptide $\mathbf{1 3}$ was prepared by cleavage of 12 directly.

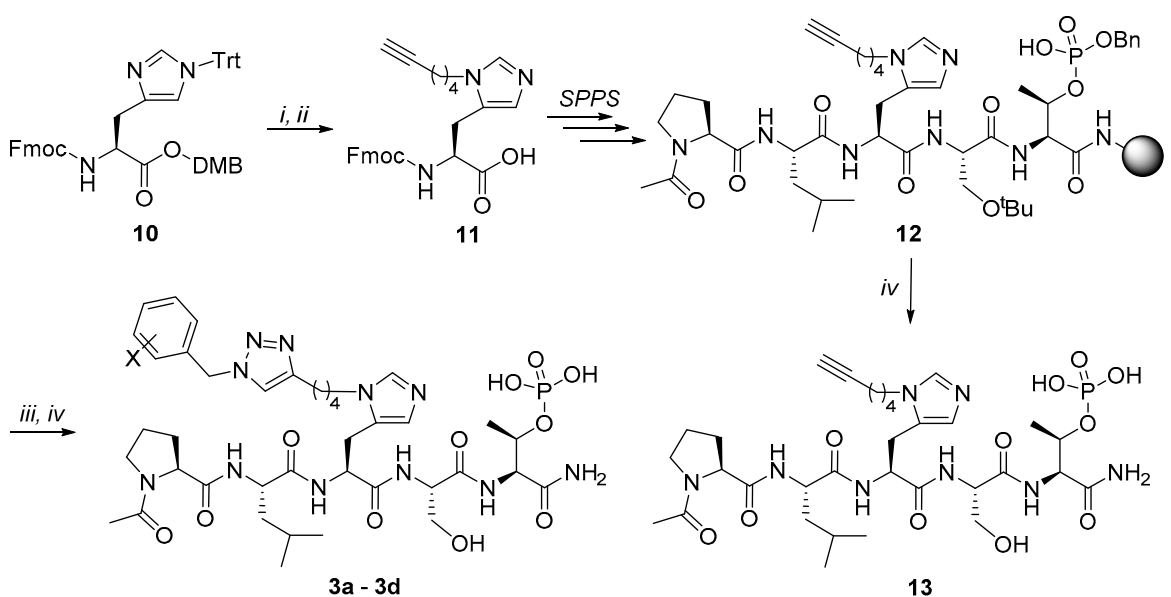

Scheme 2. Preparation of triazole-containing peptides $\mathbf{3 a - 3 d}$ and alkyne-labeled peptide $\mathbf{1 3}$. Reagents 
and Conditions: i) $\mathrm{CH} \equiv \mathrm{C}\left(\mathrm{CH}_{2}\right)_{4} \mathrm{OH}$, trifluoromethanesulfonic anhydride $\left(\mathrm{Tf}_{2} \mathrm{O}\right), \mathrm{N}, \mathrm{N}$-diisopropylethylamine (DIEA), dichloromethane (DCM); ii) trifluoroacetic acid (TFA), triisopropylsilane (TIS); iii) Bn- $\mathrm{N}_{3}$ (9a-9d), CuI, L-ascorbic acid, dimethylformamide (DMF):BuOH:Pyr (3:5:2); iv) TFA: $\mathrm{H}_{2} \mathrm{O}: \mathrm{TIS}$ (95:2.5:2.5).

Preparation of the triazole-based His mimetic containing peptide $\mathbf{4 b}$ and alkyne-labeled peptide 17 are shown in Scheme 3. Protected 15 was prepared on NovaSyn ${ }^{\circledR}$ TGR resin using commercially available Fmoc-L-propargylglycine (14) and standard Fmoc SPPS protocols. Cleavage of resin 15 and HPLC purification yielded alkyne-containing peptide 17 directly. Alternatively, an on-resin CuAAC reaction of 15 with phenyloctylazide 16 followed by resin cleavage gave peptide $\mathbf{4 b}$ after HPLC purification (Scheme 3).

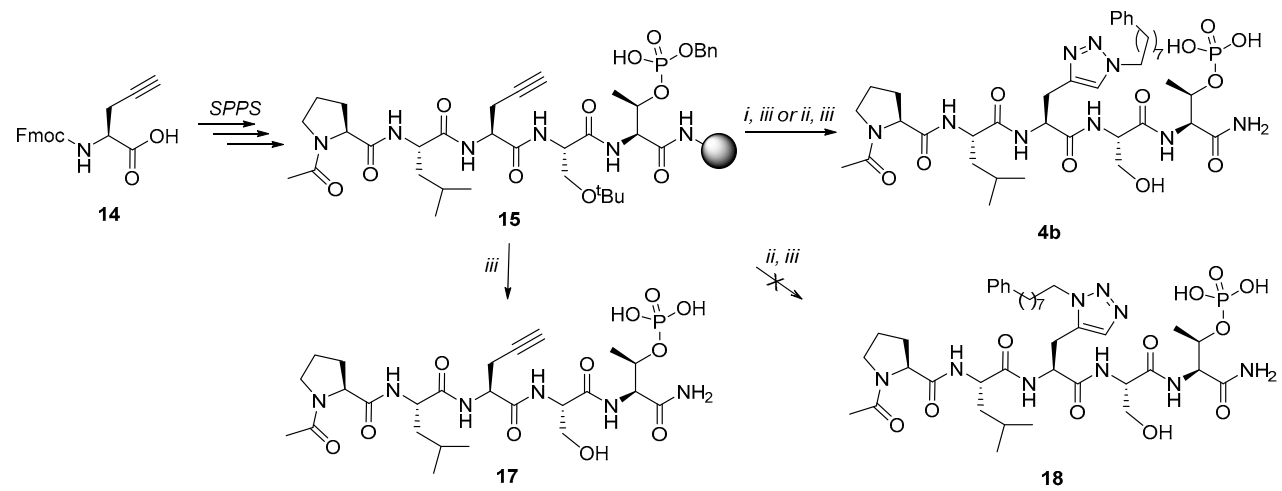

Scheme 3. Preparation of triazole-containing peptides $4 \mathrm{~b}$ and alkyne-labeled peptide 17. Reagents and Conditions: i) $\mathrm{Ph}\left(\mathrm{CH}_{2}\right)_{8} \mathrm{~N}_{3}$ (16), CuI, L-ascorbic acid, DMF:BuOH:Pyr (3:5:2); ii) $\mathrm{Cp} * \mathrm{RuCl}\left(\mathrm{PPh}_{3}\right)_{2}$, $\mathrm{Ph}\left(\mathrm{CH}_{2}\right)_{8} \mathrm{~N}_{3}$ (16), DMF; iii) TFA: $\mathrm{H}_{2} \mathrm{O}$ :TIS (95:2.5:2.5).

It was our original intent to prepare both 1,4-substituted and 1,5-substituted triazoles as mimetics of the isomeric $N(\tau)$ - and $N(\pi)$-alkylated His analogs, respectively. As stated above, the CuAAC reaction provides a reliable means for selectively assembling 1,4-disubstituted 1,2,3-triazoles [40-42]. Accordingly, when we subjected resin-bound alkyne-containing peptide 15 to CuAAC-catalyzed cycloaddition with phenyloctylazide 16, we obtained a peptide following resin cleavage and HPLC purification, whose structure we assigned as $4 \mathrm{~b}$ (Scheme 3). Alternatively, the ruthenium-catalyzed cycloaddition of azides with alkynes (RuAAC) has been reported to regioselectively yield 1,5-disubstituted 1,2,3-triazoles [43,44]. Based on this, we used the on-resin RuAAC-catalyzed $[3+2]$ cycloaddition reaction of the alkyne group of resin $\mathbf{1 5}$ and azide $\mathbf{1 6}$ with the expectation of obtaining the isomeric 1,5-substituted triazole 18 (Scheme 3). However, the resulting peptide was identical in all respects with peptide $4 \mathrm{~b}\left({ }^{1} \mathrm{H}-,{ }^{13} \mathrm{C}\right.$ - and $\left.{ }^{31} \mathrm{P}-\mathrm{NMR}\right)$. At this point, a search of the literature revealed that a simple method has been reported, which permits reliable establishment of triazole regio-substitution based on chemical shifts in one-dimensional ${ }^{13} \mathrm{C}-\mathrm{NMR}$ spectra [45]. The C5 signal of 1,4-disubstituted-1H-1,2,3-triazoles characteristically appears at approximately $\delta=120$ ppm, while the C4 signal of 1,5-disubstituted-1H-1,2,3-triazoles is usually found at $\delta=133 \mathrm{ppm}$. In our case, the products obtained from both $\mathrm{CuAAC}$ and RuAAC chemistries provided a diagnostic signal of $\delta=123.04$ ppm, indicating that the 1,4-substituted triazole $(4 \mathbf{b})$ was obtained in both cases.

\subsection{Biological Evaluation}

We employed fluorescence polarization (FP) assays to evaluate binding affinities against the isolated PBDs of Plk1, Plk2 and Plk3 (Table 1, Figure S1 in Supplementary Material). Compared with the parent peptide $1\left(\mathrm{IC}_{50}=650 \mathrm{nM}\right)$ replacement of the His imidazole ring with an alkyne group resulted in an approximate 2-fold loss of Plk1 PBD-binding affinity (17, $\mathrm{IC}_{50}=1000 \mathrm{nM}$, Table 1). Interestingly, peptide $13\left(\mathrm{IC}_{50}=1100 \mathrm{nM}\right)$ showed equivalent Plk1 PBD-binding affinity, in spite of the fact that it included a hex-5-yn-1-yl moiety at the His $N(\pi)$-position. This group would be expected to 
partially engage the hydrophobic channel leading to the cryptic pocket. We have previously shown that peptides $\mathbf{2 a}$ and $\mathbf{2 b}$ exhibit binding affinities ( $\mathrm{IC}_{50}$ values of approximately $15 \mathrm{nM}$ ) that are significantly more potent than parent peptide $\mathbf{1}$ (approximately $650 \mathrm{nM}$ ) [25,26]. Peptides $\mathbf{2 a}$ and $\mathbf{2} \mathbf{b}$ show more than 10-fold selectivity for Plk1 relative to Plk2 and approximately 70-fold and 20-fold over Plk3, respectively (Table 1 ).

Table 1. Inhibitory potencies of peptides containing different linkers using a fluorescence polarization (FP) assay. Polo-like kinase (Plk), polo-box domain (PBD).

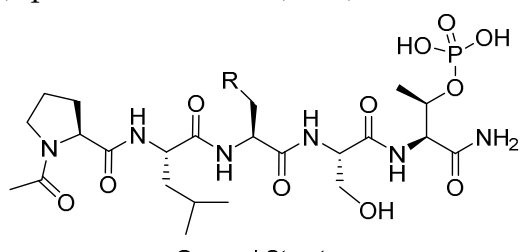

General Structure

\begin{tabular}{|c|c|c|c|c|}
\hline \multirow{2}{*}{ Peptide } & \multirow{2}{*}{$\mathbf{R}$} & \multicolumn{3}{|c|}{$\mathrm{IC}_{50}(\mathrm{nM})$} \\
\hline & & PLK1 PBD & PLK2 PBD & PLK3 PBD \\
\hline $\mathbf{1}^{i}$ & & $650 \pm 39$ & $\mathrm{ND}^{i v}$ & ND \\
\hline 17 & & $1000 \pm 140$ & ND & ND \\
\hline 13 & & $1100 \pm 45$ & ND & ND \\
\hline $2 \mathbf{a}^{i i}$ & & $15 \pm 0.94$ & $220 \pm 15$ & $1100 \pm 230$ \\
\hline $2 \mathbf{b}^{i i i}$ & & $15 \pm 0.33$ & $180 \pm 14$ & $450 \pm 87$ \\
\hline $3 a$ & & $110 \pm 6.6$ & ND & ND \\
\hline $3 b$ & & $100 \pm 19$ & ND & ND \\
\hline $3 c$ & & $130 \pm 9.8$ & ND & ND \\
\hline $3 d$ & & $25 \pm 1.6$ & $5900 \pm 420$ & $9900 \pm 2200$ \\
\hline $4 b$ & & $17 \pm 0.17$ & $690 \pm 20$ & $3400 \pm 130$ \\
\hline
\end{tabular}

${ }^{i}$ See reference [14]; ${ }^{i i}$ See reference [15]; ${ }^{i i}$ See references [25,26]; ${ }^{i v}$ Not determined. 
Peptides 3a-3d represent a series of analogs having 1,4-substituted triazoles tethered from the His $N(\pi)$-position by $-\left(\mathrm{CH}_{2}\right)_{4}$ - chains. Similar to $\mathbf{2} \mathbf{a}$ and $\mathbf{2} \mathbf{b}$, this results in a total chain extension of 8-units between the His $N(\pi)$-nitrogen and the terminal aryl group. We had previously shown that this is an optimal length by examining a series of sequentially lengthened tethers [15]. Introducing a 4-fluoro substituent $\left(\mathbf{3 b}, \mathrm{IC}_{50}=100 \mathrm{nM}\right.$, Table 1$)$ or 3 -chloro-4-fluoro substituents $\left(3 \mathbf{c}, \mathrm{IC}_{50}=130 \mathrm{nM}\right.$, Table 1$)$ were intended to potentially enhance interactions with the hydrophobic cryptic pocket. However, these did not significantly alter affinity relative to 3a. The reasons for this are not clear. Although peptide 3a was designed to mimic peptide $2 \mathbf{a}$, it shows an approximate 8 -fold relative loss of Plk1 PBD-binding affinity $\left(3 \mathbf{a}, \mathrm{IC}_{50}=110 \mathrm{nM}\right.$, Table 1$)$. In contrast to the marked loss of affinity incurred by introducing the triazole ring to $\mathbf{2} \mathbf{a}$, the triazole-containing mimetic of $\mathbf{2} \mathbf{b}$ showed good retention of Plk1 PBD-binding (3d, $\left.\mathrm{IC}_{50}=25 \mathrm{nM}\right)$. While peptides 3a-3c contain a single tethered phenyl ring, peptide $\mathbf{3 d}$ has a bis-aryl system. The greater extension afforded by this latter arrangement may permit better retention of binding interactions with the cryptic pocket than is afforded by peptides have a single phenyl ring. Importantly, 3d showed extremely high selectivity for Plk1 relative to Plk2 $\left(\mathrm{IC}_{50}=5900 \mathrm{nM}\right)$ and Plk3 $\left(\mathrm{IC}_{50}=9900 \mathrm{nM}\right)($ Table 1$)$.

In contrast to peptides $\mathbf{3 a}-\mathbf{3} \mathbf{d}$, where triazole rings were inserted into His- $N(\pi)$-tethered chains to potentially induce conformational constraint proximal to the cryptic binding pocket, peptide $4 \mathrm{~b}$ represents a triazole mimetic of the His imidazole ring. In our previous efforts to access the cryptic pocket using a variety of amino acid derivatives at the pT-2 position, the highest affinities were obtained using His residues, with alkylation at the His- $N(\pi)$ position (2a, Figure 1$)$ being significantly preferred to alkylation at the isomeric His- $N(\tau)$ position (4a, Figure 1) [24]. In spite of the fact that the 1,4-triazole substitution pattern of $\mathbf{4 b}$ does not appear to optimally replicate the geometry of the His- $N(\pi)$-1,2-imidazole pattern shown by $2 \mathbf{a}$, its Plk1 binding affinity $\left(\mathrm{IC}_{50}=17 \mathrm{nM}\right)$ equals that of 2a (Table 1). The Plk1 PBD selectivity of $\mathbf{4 b}$ is slightly better than $\mathbf{2 a}$ against the Plk2 and Plk3 PBDs (690 nM and $3400 \mathrm{nM}$, respectively).

It is known that auto-inhibitory interdomain interactions between the KD and PBD can result in decreased potencies in assays that employ full-length Plk1 relative to assays that use isolated PBD preparations, which lack a KD component [23]. The selectivity data shown in Table 1 were obtained using fluorescence polarization assays with isolated PBDs. In contrast, Table 2 shows binding data from an ELISA assay employing full-length Plk1 (Figure S2 in Supplementary Material). Peptides possessing His- $N(\pi)$-tethered chains showed an approximate order-of-magnitude potency reduction in the full-length assay relative to the isolated PBD assay (27-fold and 19-fold reductions for 2a and $\mathbf{2 b}$, respectively). However, triazole-containing peptides experienced significantly greater losses of inhibitory potency (160-fold for $\mathbf{4 b}$ and 480 -fold for $\mathbf{3 d}$ ). The larger differences may indicate a reduced ability of these peptides to effectively relieve auto-inhibition or to engage the PBD cryptic pocket in the full-length construct.

Although there are no crystals structure of full-length Plk1, which might clarify the mechanisms of autoinhibition, a co-crystal structure of Map205-stabilized isolated Plk1 KD and PBD has been solved (PDB accession code: 4J7B) [46]. In this structure the KD is situated on the face of the PBD opposite the phosphopeptide-binding site. In such an orientation, the KD displaces downward an extended loop of the PBD (residues 490-510) from where it is typically observed in isolated PBD crystal structures with bound phosphopeptides. This conformational change prevents the loop from participating in an extensive network of water-mediated hydrogen bonds with the peptide phosphate group. This may be related to the ability of the KD to inhibit ligand binding to the PBD in full-length Plk1. It is unclear from this how access to the cryptic pocket would be adversely impacted in full-length Plk1 or why the triazole-containing peptides would be more sensitive to these effects. However, it is intriguing that this loop originates from the $\alpha \mathrm{B}$ helix (residues 470-489), which forms an important component of the cryptic binding pocket. 
Table 2. PBD-binding affinities of peptides against full-length Plk1 using an ELISA assay.

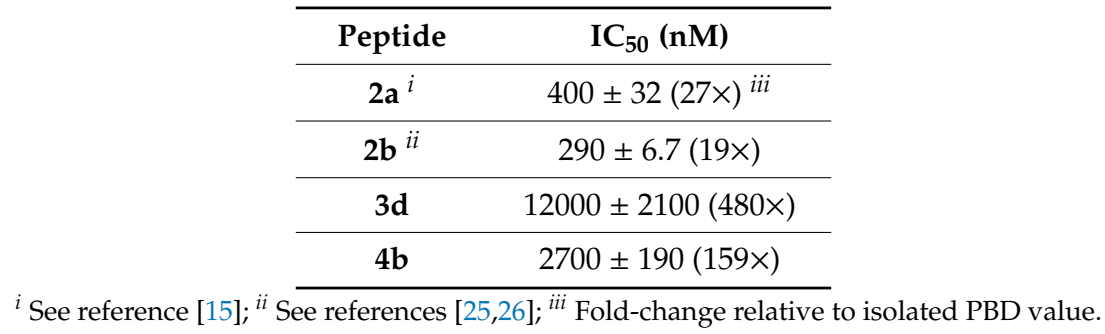

\section{Experimental Section}

\subsection{Synthesis}

\subsubsection{General Procedures}

As previously reported [26], proton $\left({ }^{1} \mathrm{H}\right)$ and carbon $\left({ }^{13} \mathrm{C}\right)$ NMR spectra were recorded on a Varian $400 \mathrm{MHz}$ spectrometer or a Varian $500 \mathrm{MHz}$ spectrometer (Varian, Palo Alto, CA, USA) and are reported in ppm relative to tetramethylsilane (TMS) and referenced to the solvent in which the spectra were collected. Solvent was removed by rotary evaporation under reduced pressure and anhydrous solvents were obtained commercially and used without further drying. Purification by silica gel chromatography was performed using Combiflash instruments (Telenyde ISCO, Lincoln, NE, USA) with EtOAc-hexanes or $\mathrm{CH}_{2} \mathrm{Cl}_{2}-\mathrm{MeOH}$ solvent systems. Preparative high pressure liquid chromatography (HPLC) was conducted using a Waters Prep LC4000 system (Waters, Milford, MA, USA) having photodiode array detection and C18 columns (catalogue No. 00G4436-P0-AX, $250 \mathrm{~mm} \times 21.2 \mathrm{~mm} 10 \mu \mathrm{m}$ particle size, $110 \AA$ pore, Phenomenex, Torrance, CA, USA) at a flow rate of $10 \mathrm{~mL} / \mathrm{min}$. Binary solvent systems consisting of $\mathrm{A}=0.1 \%$ aqueous TFA and $\mathrm{B}=0.1 \%$ TFA in acetonitrile were employed with gradients as indicated. Products were obtained as amorphous solids following lyophilization. Electrospray ionization-mass spectra (ESI-MS) were acquired with an Agilent LC/MSD system (Agilent, Santa Clara, CA, USA) equipped with a multimode ion source. High resolution mass spectrometric (HRMS, ThermoFisher Scientific, Grand Island, NY, USA) were acquired by LC/MS-ESI with a LTQ-Orbitrap-XL at $30 \mathrm{~K}$ resolution.

\subsubsection{Synthesis of 2-Fluoro-6-phenoxybenzaldehyde (6)}

According to the literatures [25,47], to a solution of 2,6-difluorobenzaldehyde (5) (11 mL, $102 \mathrm{mmol})$ and phenol $(9.6 \mathrm{~g}, 102 \mathrm{mmol})$ in dimethylacetamide (DMA) $(50 \mathrm{~mL})$ was added potassium carbonate $(14 \mathrm{~g}, 102 \mathrm{mmol})$ and the mixture was heated and refluxed $\left(165^{\circ} \mathrm{C}, 2 \mathrm{~h}\right)$. The mixture was cooled to room temperature, diluted with $\mathrm{H}_{2} \mathrm{O}(100 \mathrm{~mL})$, extracted with $\mathrm{CH}_{2} \mathrm{Cl}_{2}$ and the combined organic extract was dried $\left(\mathrm{Na}_{2} \mathrm{SO}_{4}\right)$ and concentrated. The resulting residue was purified by silica gel chromatography to afford product 6 as a colorless oil $\left(14.1 \mathrm{~g}, 64 \%\right.$ yield). ${ }^{1} \mathrm{H}-\mathrm{NMR}\left(400 \mathrm{MHz}, \mathrm{CDCl}_{3}\right) \delta 10.52(\mathrm{~s}, 1 \mathrm{H})$, 7.47-7.40 (m, 3H), 7.23 (t, $J=7.4 \mathrm{~Hz}, 1 \mathrm{H}), 7.09(\mathrm{dd}, J=8.6,1.2 \mathrm{~Hz}, 2 \mathrm{H}), 6.89-6.85(\mathrm{~m}, 1 \mathrm{H}), 6.66(\mathrm{~d}$, $J=8.5 \mathrm{~Hz}, 1 \mathrm{H}) .{ }^{13} \mathrm{C}-\mathrm{NMR}\left(101 \mathrm{MHz}, \mathrm{CDCl}_{3}\right) \delta 186.79(1 \mathrm{C}, \mathrm{d}, J=2.3 \mathrm{~Hz}), 162.90(1 \mathrm{C}, \mathrm{d}, J=263.4 \mathrm{~Hz})$, $160.50(1 \mathrm{C}, \mathrm{d}, J=5.2 \mathrm{~Hz}), 155.63,135.73(1 \mathrm{C}, \mathrm{d}, J=11.6 \mathrm{~Hz}), 130.19(2 \mathrm{C}), 124.90,119.85(2 \mathrm{C}), 116.03(1 \mathrm{C}$, $\mathrm{d}, J=9.5 \mathrm{~Hz}), 113.48(1 \mathrm{C}, \mathrm{d}, J=3.7 \mathrm{~Hz}), 110.81(\mathrm{~d}, J=21.2 \mathrm{~Hz})$. ESI-MS $m / z: 239.0\left[\mathrm{M}+\mathrm{Na}^{+}\right]$.

\subsubsection{Synthesis of (2-Fluoro-6-phenoxyphenyl)methanol (7)}

To a solution of 2-fluoro-6-phenoxybenzaldehyde (6) (5.9 g, $27 \mathrm{mmol})$ in $\mathrm{MeOH}$ (100 mL) was added sodium borohydride $(1.0 \mathrm{~g}, 27 \mathrm{mmol})$ portion-wise at $0{ }^{\circ} \mathrm{C}$ and the mixture was stirred $\left(0{ }^{\circ} \mathrm{C}\right.$, $30 \mathrm{~min}$ ), then concentrated. The resulting residue was partitioned between EtOAc and brine, dried $\left(\mathrm{Na}_{2} \mathrm{SO}_{4}\right)$, concentrated and purified by silica gel chromatography to afford product 7 as a colorless oil (5.7 g, 96\% yield). ${ }^{1} \mathrm{H}-\mathrm{NMR}\left(500 \mathrm{MHz}, \mathrm{CDCl}_{3}\right) \delta$ 7.40-7.37 (m, 2H), 7.23-7.16 (m, 2H), 7.06-7.04 $(\mathrm{m}, 2 \mathrm{H}), 6.86(\mathrm{t}, J=8.9 \mathrm{~Hz}, 1 \mathrm{H}), 6.66(\mathrm{~d}, J=8.3 \mathrm{~Hz}, 1 \mathrm{H}), 4.85(\mathrm{~s}, 2 \mathrm{H}) \cdot{ }^{13} \mathrm{C}-\mathrm{NMR}\left(126 \mathrm{MHz}, \mathrm{CDCl}_{3}\right) \delta$ 
$161.70(1 \mathrm{C}, \mathrm{d}, J=247.3 \mathrm{~Hz}), 156.95(1 \mathrm{C}, \mathrm{d}, J=7.4 \mathrm{~Hz}), 156.62,129.98(2 \mathrm{C}), 129.57(1 \mathrm{C}, \mathrm{d}, J=10.5 \mathrm{~Hz})$, 124.02, $119.41(1 \mathrm{C}, \mathrm{d}, J=18.0 \mathrm{~Hz}), 119.04(2 \mathrm{C}), 113.77(1 \mathrm{C}, \mathrm{d}, J=3.3 \mathrm{~Hz}), 110.48(1 \mathrm{C}, \mathrm{d}, J=22.6 \mathrm{~Hz})$, $54.02(1 \mathrm{C}, \mathrm{d}, J=5.1 \mathrm{~Hz})$.

\subsubsection{Synthesis of 2-(Bromomethyl)-1-fluoro-3-phenoxybenzene (8d)}

According to the literature [38], triphenylphosphine (10 g, $39 \mathrm{mmol})$ was added to a solution of (2-fluoro-6-phenoxyphenyl)-methanol (7) $(5.7 \mathrm{~g}, 26 \mathrm{mmol})$ in acetonitrile $(70 \mathrm{~mL})$ and the suspension was cooled to $0^{\circ} \mathrm{C}$ and carbon tetrabromide $(13 \mathrm{~g}, 39 \mathrm{mmol})$ was added. The suspension turned to a clear brown solution and then to a white suspension after $2 \mathrm{~min}$. The reaction suspension was stirred (room temperature, $30 \mathrm{~min}$ ), then diluted with EtOAc and the organic phase was concentrated and purified by silica gel chromatography to provide product $\mathbf{8 d}$ as a colorless oil $(7.4 \mathrm{~g}, 99 \%$ yield). ${ }^{1} \mathrm{H}-\mathrm{NMR}\left(500 \mathrm{MHz}, \mathrm{CDCl}_{3}\right)$ 8 7.43-7.40 (m, 2H), 7.23-7.19 (m, 2H), 7.12-7.09 (m, 2H), $6.86(\mathrm{t}, J=9.2 \mathrm{~Hz}$, $1 \mathrm{H}), 6.63(\mathrm{~d}, J=8.4 \mathrm{~Hz}, 1 \mathrm{H}), 4.70(\mathrm{~d}, J=1.3 \mathrm{~Hz}, 2 \mathrm{H}) .{ }^{13} \mathrm{C}-\mathrm{NMR}\left(126 \mathrm{MHz}, \mathrm{CDCl}_{3}\right) \delta 161.56(1 \mathrm{C}, \mathrm{d}$, $J=250.5 \mathrm{~Hz}), 156.91(1 \mathrm{C}, \mathrm{d}, J=6.4 \mathrm{~Hz}), 156.34,130.16(1 \mathrm{C}, \mathrm{d}, J=10.5 \mathrm{~Hz}), 129.98(2 \mathrm{C}), 124.30,119.61$ (2C), $117.10(1 \mathrm{C}, \mathrm{d}, J=17.2 \mathrm{~Hz}), 113.42(1 \mathrm{C}, \mathrm{d}, J=3.2 \mathrm{~Hz}), 110.11(1 \mathrm{C}, \mathrm{d}, J=21.6 \mathrm{~Hz}), 20.10(1 \mathrm{C}, \mathrm{d}$, $J=5.4 \mathrm{~Hz})$.

\subsubsection{General Procedure A for the Synthesis of Azides 9a-9d and $\mathbf{1 6}$}

To a solution of bromides $\mathbf{8 a - 8 d}$ or commercially available (8-bromooctyl)benzene $(7.0 \mathrm{mmol})$ in acetone $(10 \mathrm{~mL})$ and $\mathrm{H}_{2} \mathrm{O}(2.0 \mathrm{~mL})$ was added sodium azide $(1.8 \mathrm{~g}, 28 \mathrm{mmol})$ and the mixture was stirred $\left(55^{\circ} \mathrm{C}, 15 \mathrm{~h}\right)$. The reaction was quenched by the addition of $\mathrm{H}_{2} \mathrm{O}$, extracted with $\mathrm{Et}_{2} \mathrm{O}$ and the combined organic phase was washed with brine, dried $\left(\mathrm{Na}_{2} \mathrm{SO}_{4}\right)$, concentrated and purified by silica gel chromatography to provide the target azides $9 \mathrm{a}-\mathbf{9 d}$, and $\mathbf{1 6}$.

\subsubsection{Synthesis of (Azidomethyl)benzene (9a)}

According to the literature [48], treatment of (bromomethyl)benzene (8a) [48] as outlined in general procedure A provided title compound 9a as a colorless oil (57\% yield). ESI-MS m/z: 106.1 $\left(\mathrm{MH}^{+}-\mathrm{N}_{2}\right)$.

\subsubsection{Synthesis of 1-(Azidomethyl)-4-fluorobenzene (9b)}

Treatment of 1-(bromomethyl)-4-fluorobenzene $(\mathbf{8 b})$ as outlined in general procedure A provided the title compound $\mathbf{9 b}$ as a colorless oil $\left(82 \%\right.$ yield). ${ }^{1} \mathrm{H}-\mathrm{NMR}\left(500 \mathrm{MHz}, \mathrm{CDCl}_{3}\right) \delta 7.32(\mathrm{dd}, \mathrm{J}=8.4$, $5.4 \mathrm{~Hz}, 2 \mathrm{H}), 7.10(\mathrm{t}, J=8.6 \mathrm{~Hz}, 2 \mathrm{H}), 4.34(\mathrm{~s}, 2 \mathrm{H})$. ESI-MS m/z: $124.1\left(\mathrm{MH}^{+}-\mathrm{N}_{2}\right)$.

\subsubsection{Synthesis of 4-(Azidomethyl)-2-chloro-1-fluorobenzene (9c)}

Treatment of 4-(bromomethyl)-2-chloro-1-fluorobenzene (8c) as outlined in general procedure A provided the title compound $9 \mathrm{c}$ as a colorless oil (49\% yield). ${ }^{1} \mathrm{H}-\mathrm{NMR}\left(500 \mathrm{MHz}, \mathrm{CDCl}_{3}\right) \delta 7.40$ (dd, $J=6.9,2.1 \mathrm{~Hz}, 1 \mathrm{H}), 7.22(\mathrm{ddd}, J=7.0,4.7,2.1 \mathrm{~Hz}, 1 \mathrm{H}), 7.18(\mathrm{t}, J=8.5 \mathrm{~Hz}, 1 \mathrm{H}), 4.34(\mathrm{~s}, 2 \mathrm{H}) .{ }^{13} \mathrm{C}-\mathrm{NMR}$ $\left(126 \mathrm{MHz}, \mathrm{CDCl}_{3}\right) \delta 157.94(\mathrm{~d}, J=249.9 \mathrm{~Hz}), 132.53(\mathrm{~d}, J=4.0 \mathrm{~Hz}), 130.37,127.85(\mathrm{~d}, J=7.3 \mathrm{~Hz}), 121.46$ $(\mathrm{d}, J=18.0 \mathrm{~Hz}), 116.96(\mathrm{~d}, J=21.4 \mathrm{~Hz}), 53.54$. ESI-MS $m / z: 158.1\left(\mathrm{MH}^{+}-\mathrm{N}_{2}\right)$

\subsubsection{Synthesis of 2-(Azidomethyl)-1-fluoro-3-phenoxybenzene (9d)}

Treatment of 2-(bromomethyl)-1-fluoro-3-phenoxybenzene (8d) as outlined in general procedure A provided the title compound $9 \mathrm{~d}$ as a colorless oil (58\% yield). ${ }^{1} \mathrm{H}-\mathrm{NMR}\left(400 \mathrm{MHz}, \mathrm{CDCl}_{3}\right) \delta 7.79$ $(\mathrm{t}, J=7.9 \mathrm{~Hz}, 2 \mathrm{H}), 7.67-7.63(\mathrm{~m}, 1 \mathrm{H}), 7.61-7.57(\mathrm{~m}, 1 \mathrm{H}), 7.47-7.45(\mathrm{~m}, 2 \mathrm{H}), 7.28(\mathrm{t}, J=8.6 \mathrm{~Hz}, 1 \mathrm{H})$, $7.05(\mathrm{~d}, J=8.4 \mathrm{~Hz}, 1 \mathrm{H}), 4.91(\mathrm{~s}, 2 \mathrm{H}) .{ }^{13} \mathrm{C}-\mathrm{NMR}\left(101 \mathrm{MHz}, \mathrm{CDCl}_{3}\right) \delta 162.04(\mathrm{~d}, J=248.7 \mathrm{~Hz}), 157.26$ $(\mathrm{d}, J=7.0 \mathrm{~Hz}), 156.14,130.29(\mathrm{~d}, J=10.5 \mathrm{~Hz}), 130.00(2 \mathrm{C}), 124.30,119.47(2 \mathrm{C}), 114.17(\mathrm{~d}, J=18.2 \mathrm{~Hz})$, $113.12(\mathrm{~d}, J=3.3 \mathrm{~Hz}), 110.09(\mathrm{~d}, J=22.2 \mathrm{~Hz}), 42.55(\mathrm{~d}, J=4.0 \mathrm{~Hz})$. ESI-MS m/z: $216.1\left(\mathrm{MH}^{+}-\mathrm{N}_{2}\right)$. 


\subsubsection{Synthesis of (8-Azidooctyl)benzene (16)}

Treatment of commercially available (8-bromooctyl)benzene as outlined in general procedure A provided the title compound 16 as a colorless oil (68\% yield). ${ }^{1} \mathrm{H}-\mathrm{NMR}\left(400 \mathrm{MHz}, \mathrm{CDCl}_{3}\right) \delta 7.32-7.28$ $(\mathrm{m}, 2 \mathrm{H}), 7.22-7.18(\mathrm{~m}, 3 \mathrm{H}), 3.28(\mathrm{t}, J=7.0 \mathrm{~Hz}, 2 \mathrm{H}), 2.64(\mathrm{t}, J=7.7 \mathrm{~Hz}, 2 \mathrm{H}), 1.66-1.58(\mathrm{~m}, 4 \mathrm{H}), 1.41-1.33$ (m, 8H). ${ }^{13} \mathrm{C}-\mathrm{NMR}\left(101 \mathrm{MHz}, \mathrm{CDCl}_{3}\right) \delta 142.82,128.39$ (2C), 128.23 (2C), 125.59, 51.49, 35.96, 31.45, 29.34, 29.19, 29.08, 28.84, 26.71. ESI-MS m/z: $204.2\left(\mathrm{MH}^{+}-\mathrm{N}_{2}\right)$.

\subsubsection{Synthesis of $N^{\alpha}-\left(((9 H-F l u o r e n-9-y l) m e t h o x y)\right.$ carbonyl)- $N^{\pi}-($ hex-5-yn-1-yl)-L-histidine (11)}

As previously reported [39], to a solution of trifluoromethanesulfonic anhydride $(2.8 \mathrm{~mL}$, $2.8 \mathrm{mmol})$ in $\mathrm{CH}_{2} \mathrm{Cl}_{2}(5.0 \mathrm{~mL})$ was added a solution of hex-5-yn-1-ol $(0.31 \mathrm{~mL}, 2.8 \mathrm{mmol})$ and $\mathrm{N}$ ethyl-N-isopropylpropan-2-amine $\left(0.49 \mathrm{~mL}, 2.8 \mathrm{mmol}, 1.0 \mathrm{M}\right.$ in $\left.\mathrm{CH}_{2} \mathrm{Cl}_{2}\right)$ in $\mathrm{CH}_{2} \mathrm{Cl}_{2}(10 \mathrm{~mL})$ dropwise under argon at $-78{ }^{\circ} \mathrm{C}$ and the mixture was stirred at $-78{ }^{\circ} \mathrm{C}(20 \mathrm{~min})$. To this was added a solution of (S)-2,4-dimethoxybenzyl 2-((( $9 H$-fluoren-9-yl)methoxy)carbonyl)amino)-3-(1-trityl-1H-imidazol-4yl)propanoate (10) [24] $(2.0 \mathrm{~g}, 2.5 \mathrm{mmol})$ in $\mathrm{CH}_{2} \mathrm{Cl}_{2}(5.0 \mathrm{~mL})$ at $-78{ }^{\circ} \mathrm{C}$ and the mixture was allowed to come to room temperature and stirred (overnight). The solvent was removed by evaporation and a solution of TFA:TIS (10:1, $10 \mathrm{~mL})$ was added and the mixture was stirred at room temperature $(2 \mathrm{~h})$. The reaction mixture was concentrated and the resulting residue was purified by silica gel chromatography to provide the title compound 11 as a colorless sticky oil (0.53 g, 46\% yield). ESI-MS m/z: $458.2\left(\mathrm{MH}^{+}\right)$.

\subsection{Peptide Synthesis}

\subsubsection{General Solid-Phase Peptide Synthesis (SPPS)}

As previously reported [26], the protected amino acids used were Fmoc-L-Thr(PO(OBzl)OH)-OH, Fmoc-L-Ser $\left(\mathrm{O}^{t} \mathrm{Bu}\right)-\mathrm{OH}$, Fmoc-L-Leu-OH, and Fmoc-L-Pro-OH (purchased from Novabiochem, MilliporeSigma, Burlington, MA, USA). Peptides were synthesized on a NovaSyn ${ }^{\circledR}$ TGR resin (Novabiochem Cat\#. 855009) using standard Fmoc SPPS protocols in N-methyl-2-pyrrolidone (NMP). Coupling reagents used were 1-[bis(dimethylamino)methylene]-1H-1,2,3-triazolo[4,5-b]pyridinium 3-oxid hexafluorophosphate (HATU) (5.0 equivalents) and $N, N$-diisopropylethylamine (DIPEA) (10 equivalents). Non-coded amino acid residues were coupled using 2.5 equivalents amino acids. Deprotection was performed using 20\% piperidine in DMF (15 min, twice). Amino-terminal acetylation was performed using 1-acetylimidazole. Finished resins were washed with NMP, $\mathrm{MeOH}, \mathrm{CH}_{2} \mathrm{Cl}_{2}$, and $\mathrm{Et}_{2} \mathrm{O}$, dried under vacuum and cleaved by treatment with a solution of TFA: $\mathrm{H}_{2} \mathrm{O}: \mathrm{TIS}$ (95:2.5:2.5) (5 h). The resin was removed by filtration, and the filtrate was concentrated under vacuum and the resulting residue was dissolved in $50 \%$ aqueous acetonitrile $(5 \mathrm{~mL})$ and purified by reverse-phase HPLC as outline above in General Synthetic Procedures.

\subsubsection{Synthesis of Peptides 3a-3d and $\mathbf{4 b}$ Using On-resin Copper-catalyzed Alkyne-azide} Cycloaddition Reaction (CuAAC)

By sequential coupling, Fmoc-Thr(PO(OBzl)OH)-OH, Fmoc-Ser $\left(\mathrm{O}^{t} \mathrm{Bu}\right)-\mathrm{OH}$, alkynyl-labelled $N(\pi)$-alkylated Fmoc-His-OH (11) or Fmoc-L-propargylglycine (14), Fmoc-Leu-OH, and Fmoc-Pro$\mathrm{OH}$ were loaded onto NovaSyn ${ }^{\circledR}$ TGR resin using the general SPPS protocols outlined above. The pre-loaded resin $(\mathbf{1 2}$ or $\mathbf{1 5}, 0.02 \mathrm{mmol})$ was mixed with a solution of azides (9a-9d or 16) (0.14 mmol), copper(I) iodide $(0.26 \mathrm{mmol})$, DIEA $(0.34 \mathrm{mmol})$ and L-ascorbic acid $(0.14 \mathrm{mmol})$ in BuOH:DMF:pyridine $(5: 3: 2,1.5 \mathrm{~mL})$ and the mixture was stirred $(17 \mathrm{~h})$. The resin was washed with $\mathrm{NMP}, \mathrm{MeOH}, \mathrm{CH}_{2} \mathrm{Cl}_{2}$, and $\mathrm{Et}_{2} \mathrm{O}$, dried under vacuum and then cleaved by treatment with a solution of TFA: $\mathrm{H}_{2} \mathrm{O}: \mathrm{TIS}$ (95:2.5:2.5) $(5 \mathrm{~h})$. The resin was removed by filtration and the filtrate was concentrated under vacuum and the resulting residue was subjected to preparative HPLC purification. 
3.2.3. Synthesis of Peptide $\mathbf{4 b}$ Using On-resin Ruthenium-catalyzed Alkyne-azide Cycloaddition Reaction (RuAAC)

According to literature [36,49], pre-loaded alkyne-labeled NovaSyn ${ }^{\circledR}$ TGR resin 15 (0.049 mmol) was mixed with $\mathrm{Cp} * \mathrm{RuCl}\left(\mathrm{PPh}_{3}\right)_{2}$ [pentamethylcyclopentadienylbis(triphenylphosphine) ruthenium (II) chloride] $(0.049 \mathrm{mmol})$ in DMF $(1.0 \mathrm{~mL})$ at room temperature $(1 \mathrm{~h})$. A solution of (8-azidooctyl)benzene (16) $(56 \mathrm{mg}, 0.24 \mathrm{mmol})$ in DMF $(1.0 \mathrm{~mL})$ was added and the mixture was stirred at room temperature (24 h). The resulting dark brown resin was washed with $\mathrm{NMP}, \mathrm{MeOH}, \mathrm{CH}_{2} \mathrm{Cl}_{2}$, and $\mathrm{Et}_{2} \mathrm{O}$, dried under vacuum and cleaved by treatment with a solution of TFA: $\mathrm{H}_{2} \mathrm{O}: \mathrm{TIS}(95: 2.5: 2.5)(5 \mathrm{~h})$. The resin was removed by filtration and the filtrate was concentrated under vacuum and the resulting residue was purified by preparative HPLC.

\subsubsection{Peptide Data}

Peptide 3a. Linear gradient of $0 \% \mathrm{~B}$ to $80 \% \mathrm{~B}$ over $30 \mathrm{~min}$, retention time $=16.0 \mathrm{~min}$. ESI-MS $\mathrm{m} / \mathrm{z}: 888.4$ $\left(\mathrm{MH}^{+}\right)$. HRMS calcd $\mathrm{C}_{39} \mathrm{H}_{59} \mathrm{~N}_{11} \mathrm{O}_{11} \mathrm{P}\left(\mathrm{MH}^{+}\right)$, 888.4128; found, 888.4139.

Peptide $3 \mathbf{b}$. Linear gradient of $0 \% \mathrm{~B}$ to $80 \%$ B over $30 \mathrm{~min}$, retention time $=16.4 \mathrm{~min}$. ESI-MS $\mathrm{m} / \mathrm{z}: 906.4$ $\left(\mathrm{MH}^{+}\right)$. HRMS calcd $\mathrm{C}_{39} \mathrm{H}_{58} \mathrm{FN}_{11} \mathrm{O}_{11} \mathrm{P}\left(\mathrm{MH}^{+}\right)$, 906.4033; found, 906.4045 .

Peptide 3c. Linear gradient of $0 \%$ B to $80 \%$ B over $30 \mathrm{~min}$, retention time $=17.0 \mathrm{~min}$. ESI-MS $\mathrm{m} / \mathrm{z}: 940.3$ $\left(\mathrm{MH}^{+}\right)$. HRMS calcd $\mathrm{C}_{39} \mathrm{H}_{57} \mathrm{ClFN}_{11} \mathrm{O}_{11} \mathrm{P}\left(\mathrm{MH}^{+}\right)$, 940.3644; found, 940.3650.

Peptide 3d. Linear gradient of $0 \% \mathrm{~B}$ to $80 \%$ B over $30 \mathrm{~min}$, retention time $=17.8 \mathrm{~min}$. ESI-MS $\mathrm{m} / \mathrm{z}: 998.2$ $\left(\mathrm{MH}^{+}\right)$. HRMS calcd $\mathrm{C}_{45} \mathrm{H}_{62} \mathrm{FN}_{11} \mathrm{O}_{12} \mathrm{P}\left(\mathrm{MH}^{+}\right)$, 998.4296; found, 998.4311.

Peptide $\mathbf{4 b}$. Linear gradient of $0 \% \mathrm{~B}$ to $80 \%$ B over $30 \mathrm{~min}$, retention time $=22.6 \mathrm{~min}$. ESI-MS $\mathrm{m} / \mathrm{z}: 864.4$ $\left(\mathrm{MH}^{+}\right)$. HRMS calcd $\mathrm{C}_{39} \mathrm{H}_{63} \mathrm{~N}_{9} \mathrm{O}_{11} \mathrm{P}\left(\mathrm{MH}^{+}\right)$: 864.4379; found, 864.4365 .

Peptide 13. Linear gradient of $0 \% \mathrm{~B}$ to $80 \% \mathrm{~B}$ over $30 \mathrm{~min}$, retention time $=14.8 \mathrm{~min}$. ESI-MS $\mathrm{m} / \mathrm{z}: 755.3$ $\left(\mathrm{MH}^{+}\right)$. HRMS calcd $\mathrm{C}_{32} \mathrm{H}_{52} \mathrm{~N}_{8} \mathrm{O}_{11} \mathrm{P}\left(\mathrm{MH}^{+}\right)$: 755.3488; found, 755.3497.

Peptide 17. Linear gradient of $0 \% \mathrm{~B}$ to $80 \% \mathrm{~B}$ over $30 \mathrm{~min}$, retention time $=15.0 \mathrm{~min}$. ESI-MS $\mathrm{m} / \mathrm{z}: 633.2$ $\left(\mathrm{MH}^{+}\right)$. HRMS calcd $\mathrm{C}_{25} \mathrm{H}_{42} \mathrm{~N}_{6} \mathrm{O}_{11} \mathrm{P}\left(\mathrm{MH}^{+}\right)$, 633.2644; found, 633.2625.

\subsection{Determination of Binding Selectivity against the PBDs of Plks 1-3 Using Fluorescence Polarization}

\subsubsection{Expression and Purification of Isolated PBDs of Plks 1-3 for Fluorescence Polarization Assays}

As previously reported $[25,26,50]$, a plasmid encoding myc-tagged Plk1 PBD was purchased from Addgene (Plasmid \#41162, Watertown, MA, USA) [51]. Plasmids encoding the myc-tagged PBDs of Plk2 and Plk3 were generous gifts from Prof. Erich Nigg (Univ. of Basel, Basel, Switzerland) [51]. $\sim 20$ M HEK (human embryonic kidney)-293T cells $(2 \times 15 \mathrm{~cm}$ plates) were transfected with each plasmid using TurboFect reagent. Following $24 \mathrm{~h}$ expression, cells were harvested, lysed in buffer [phosphate buffered saline (PBS, pH 7.4) containing $0.5 \%$ NP-40 and protease/phosphatase inhibitor cocktail] using freeze/thaw cycles ( $3 \times)$ and centrifuged at $12,500 \times g$ for $10 \mathrm{~min}$ at $4{ }^{\circ} \mathrm{C}$. The supernatant containing expressed protein was diluted into $8 \mathrm{~mL}$ of $\mathrm{PBS}$ (pH 7.4) containing protease/phosphatase inhibitor cocktail. This protein solution was added to a $1 \mathrm{~mL}$ bed of myc-agarose resin (Thermo Scientific, Waltham, MA, USA) and allowed to bind for $2 \mathrm{~h}$ at $4{ }^{\circ} \mathrm{C}$ with gentle rotation. The lysate was eluted and the resin was washed $4 \times$ with 4-(2-hydroxyethyl)-1-piperazineethanesulfonic acid (HEPES) buffered saline (HBS) containing 0.05\% Tween-20, $1 \mathrm{mM}$ dithiothreitol (DTT) and $1 \mathrm{mM}$ ethylenediaminetetraacetic acid (EDTA). The bound PBD protein was then eluted with a $1 \mathrm{mg} / \mathrm{mL}$ solution of myc peptide (EQKLISEEDL) in HBS + $1 \mathrm{mM}$ DTT and $1 \mathrm{mM}$ EDTA. The purified PBD protein was dialyzed $5 \times$ with HBS $+1 \mathrm{mM}$ DTT and $1 \mathrm{mM}$ EDTA using a $10 \mathrm{kDa}$ molecular weight cut-off (MWCO) filter (Sigma-Aldrich, St. Louis, MO, USA) fixed angle rotor at $7500 \times g, 4{ }^{\circ} \mathrm{C}, 10 \mathrm{~min}$ ). The concentration of the final protein solution was determined by absorbance at $280 \mathrm{~nm}$ and purity 
was determined by SDS-PAGE (sodium dodecyl sulfate-polyacrylamide gel electrophoresis) with Coomassie staining.

3.3.2. Evaluation of Binding Affinities against the Isolated PBDs of Plk1, Plk2 and Plk3 Using Fluorescence Polarization Assays

As previously reported $[25,26,50]$, isolated PBD protein was diluted to a $2 \times$ working dilution in assay buffer (HEPES-buffered saline with 0.05\% Tween-20, $1 \mathrm{mM}$ DTT, and $1 \mathrm{mM}$ EDTA). The following final protein concentrations used were: $80 \mathrm{nM}$ for Plk1 PBD; $80 \mathrm{nM}$ for Plk2 PBD and $130 \mathrm{nM}$ for Plk3 PBD. These concentrations represent the approximate $K_{d}$ values determined for the respective fluorescence polarization probe sequences. Inhibitors were serially diluted to generate $4 \times$ working dilutions in assay buffer containing $4 \%$ DMSO. $20 \mu \mathrm{L}$ of $2 \times$ PBD solution was added to each well of a 384-well plate ( $0 \%$ binding controls received $20 \mu \mathrm{L}$ of assay buffer). $10 \mu \mathrm{L}$ of the $4 \times$ inhibitor solution (or DMSO blank) was added to corresponding wells and allowed to pre-incubate at RT for $30 \mathrm{~min}$ with shaking. The following sequences were utilized as fluorescent probes: 5CF-GPMQSpTPLNG-NH $\mathrm{N}_{2}$ for Plk1 PBD; 5CF-GPMQTSpTPKNG-NH ${ }_{2}$ for Plk2 PBD and 5CF-PLATSpTPKNG-NH ${ }_{2}$ for Plk3 PBD [10]. Fluorescent probes were diluted to $40 \mathrm{nM}(4 \times)$ in assay buffer and then $10 \mu \mathrm{L}$ was added to each well. The plate was allowed to equilibrate at room temperature for $(30 \mathrm{~min})$ with shaking. The FP was read using a BioTek Synergy 2 plate reader (BioTek, Winooski, VT, USA) with 485/20 excitation and 528/20 emission. The FP values were obtained in triplicate and normalized to $100 \%$ (no inhibitor) and $0 \%$ binding (no protein) controls. Normalized values were plotted versus concentration and analyzed using non-linear regression in GraphPad Prism 8 (GraphPad Software, San Diego, CA, USA) [ $\log$ (inhibitor) vs. response-variable slope (four parameter) model]. $\mathrm{IC}_{50}$ values are presented in Table 1 and represent average \pm standard error of the mean (SEM).

\subsection{Evaluation of Binding Affinities against Full-length Plk1 Using ELISA Assays}

\subsubsection{Lysate Production for ELISA-based Inhibition Assay against Full Length Plk1}

Assays were conducted as previously reported $[25,26,50]$. To summarize, a plasmid encoding myc-tagged full-length Plk1 (Addgene, Plasmid \#41160) [52] was transiently transfected into HEK (human embryonic kidney)-293T cells using the TurboFect reagent (Thermo Scientific, Waltham, MA, USA) according to manufacturer's instructions. Following $48 \mathrm{~h}$ expression, cells were harvested, lysed in buffer (PBS, pH 7.4 with $0.5 \%$ NP-40 and protease/phosphatase inhibitor cocktail) using freeze/thaw cycles $(3 \times)$ and centrifuged at $10,000 \times g$ for $10 \mathrm{~min}$ at $4{ }^{\circ} \mathrm{C}$. The supernatant was removed to provide a crude cytosolic lysate containing overexpressed, myc-tagged Plk1 (total protein concentration determined by bicinchoninic acid (BCA) assay).

\subsubsection{Determination of Inhibitory Potency in an ELISA Assay Using Full-Length Plk1}

As previously reported $[25,26,50]$ a biotinylated phosphopeptide (sequence: Biotin-AhxPMQS(pT)PLN-NH ${ }_{2}$ ) was diluted to $1 \mu \mathrm{M}$ (from a $2 \mathrm{mM}$ DMSO stock solution) in PBS ( $\mathrm{pH}$ 7.4) and loaded onto the wells of a 96-well Neutravidin-coated plate (Pierce Biotechnology, ThermoFisher Scientific, Waltham, MA, USA) at $100 \mu \mathrm{L}$ per well for $1 \mathrm{~h}$ (background control contained no biotinylated peptide). The wells were washed once with $150 \mu \mathrm{L}$ PBST (PBS, pH $7.4+0.05 \%$ Tween-20), and then $100 \mu \mathrm{L}$ of $1 \%$ BSA in PBS (pH 7.4) (blocking buffer) was added for $1 \mathrm{~h}$. A cytosolic lysate-containing transiently expressed myc-tagged Plk1 protein was diluted to $300 \mu \mathrm{g} / \mathrm{mL}$ in PBS (pH 7.4) containing protease/phosphatase inhibitors (Pierce Biotechnology), mixed with competitive inhibitor (from a $10 \times$ stock in $\sim 4 \%$ DMSO/PBS), and allowed to pre-incubate for $1 \mathrm{~h}(100 \mu \mathrm{L}$ per well in a 96-well plate, $30 \mu \mathrm{g}$ total protein). The blocked ELISA plate was washed $2 \times$ with PBST (PBS, pH $7.4+0.05 \%$ Tween-20) $(150 \mu \mathrm{L})$ and the pre-incubated lysates were added to the plate and incubated $(1 \mathrm{~h})$. The wells were washed $4 \times$ with PBST $(150 \mu \mathrm{L})$ and then treated with anti-myc primary antibody $(1: 1500$ dilution in PBS, mouse monoclonal, Pierce Biotechnology) for $1 \mathrm{~h}$. The wells were then washed $4 \times$ 
with PBST $(150 \mu \mathrm{L})$, and incubated with rabbit anti-mouse horseradish peroxidase (HRP) conjugate [1:3000 dilution in $1 \%(\% w / v)$ BSA in PBS, Pierce Biotechnology] for $1 \mathrm{~h}$. The wells were then washed $5 \times$ with PBST $(150 \mu \mathrm{L})$ and incubated with Turbo TMB $\left(3,3^{\prime}, 5,5^{\prime}\right.$-tetramethyl benzidine substrate)-ELISA solution (Pierce Biotechnology) until the desired absorbance was reached (5-10 $\mathrm{min}$ ). The reaction was quenched by the addition of $2 \mathrm{~N}$ aqueous $\mathrm{H}_{2} \mathrm{SO}_{4}$ and the absorbance was measured at $450 \mathrm{~nm}$ using a BioTek Synergy 2 96-well plate reader. Absorbance was plotted versus concentration $(\log \mathrm{M})$ and fit to a non-linear regression analysis using GraphPad Prism 8 software [model: $\log$ (inhibitor) vs. response-variable slope (four parameters)]. The calculated $\mathrm{IC}_{50}$ values presented in Table 2 are from multiple independent experiments and were normalized and averaged to provide values \pm SEM.

\section{Conclusions}

Presented herein are the design of the triazole-containing conformationally constrained peptides $\mathbf{3 a}-\mathbf{3} \mathbf{d}$ and the His mimic-containing peptide $\mathbf{4} \mathbf{b}$ as well as their facile preparation using on-resin azide-alkyne cycloaddition reactions. The resulting peptides were evaluated in FP binding assays using isolated PBDs of Plk1, Plk2 and Plk3 and in ELISA assays against full-length Plk1. Certain of these new ligands retain the high Plk1 PBD-binding affinity of the parent peptide $\mathbf{2 a}$, while having enhanced selectivity for the PBD of Plk1 relative to the PBDs of Plk2 and Plk3. It is interesting that peptides $\mathbf{4 b}$ and 3d show significantly greater than anticipated reduced affinities in full-length Plk1 ELISA assays relative to values obtained with the isolated PBD ( 160 -fold for $\mathbf{4 b}$ and 480 -fold for $\mathbf{3 d}$ ). The larger differences may indicate a reduced ability of these triazole-containing peptides to effectively relieve auto-inhibition arising from interdomain interactions between the KD and PBD or to engage the PBD cryptic pocket in the full-length construct. These observations are noteworthy, in that they potentially indicate structural interactions of the KD and PBD in full-length Plk1 that are not anticipated by the previous co-crystal structure of isolated KD and PBD in the presence of Map205.

Supplementary Materials: Supplementary material associated with this article is available online. Figures S1 and S2 reporting FP binding data against the isolated PBDs of Plk1, Plk2 and Plk3 and ELISA binding assays against full-length Plk1.

Author Contributions: X.Z.Z. designed and synthesized the peptides. K.T. and D.H. performed the biological evaluation. X.Z.Z., K.T., D.H. and T.R.B.Jr. interpreted the data and wrote the paper. All authors have approved the final manuscript.

Funding: This work was supported by the Intramural Research Program of the NIH, Center for Cancer Research, National Cancer Institute, National Institutes of Health. This work was supported in part by a JSPS Research Fellowship for Japanese Biomedical and Behavioral Researchers at NIH.

Acknowledgments: We thank Joseph Barchi (Chemical Biology Laboratory, NCI, NIH) for helpful discussion concerning NMR and James A. Kelley and Christopher C. Lai (Chemical Biology Laboratory, NCI, NIH) for HRMS data.

Conflicts of Interest: The authors declare no conflict of interest.

\section{References}

1. Zitouni, S.; Nabais, C.; Jana, S.C.; Guerrero, A.; Bettencourt-Dias, M. Polo-like kinases: Structural variations lead to multiple functions. Nat. Rev. Mol. Cell Biol. 2014, 15, 433-452. [CrossRef] [PubMed]

2. Park, J.-E.; Erikson, R.L.; Lee, K.S. Feed-forward mechanism of converting biochemical cooperativity to mitotic processes at the kinetochore plate. Proc. Natl. Acad. Sci. USA 2011, 108, 8200-8205. [CrossRef] [PubMed]

3. Lowery, D.M.; Lim, D.; Yaffe, M.B. Structure and function of polo-like kinases. Oncogene 2005, 24, $248-259$. [CrossRef] [PubMed]

4. Strebhardt, K.; Ullrich, A. Targeting polo-like kinase 1 for cancer therapy. Nat. Rev. Cancer 2006, 6, 321-330. [CrossRef]

5. Park, J.-E.; Soung, N.-K.; Johmura, Y.; Kang, Y.H.; Liao, C.; Lee, K.H.; Park, C.H.; Nicklaus, M.C.; Lee, K.S. Polo-box domain: A versatile mediator of polo-like kinase function. Cell. Mol. Life Sci. 2010, 67, 1957-1970. [CrossRef] 
6. Strebhardt, K. Multifaceted polo-like kinases: Drug targets and antitargets for cancer therapy. Nat. Rev. Drug Discov. 2010, 9, 643-660. [CrossRef]

7. Lee, K.S.; Burke, T.R., Jr.; Park, J.-E.; Bang, J.K.; Lee, E. Recent advances and new strategies in targeting Plk1 for anticancer therapy. Trends Pharmacol. Sci. 2015, 36, 858-877. [CrossRef]

8. Archambault, V.; Lepine, G.; Kachaner, D. Understanding the polo kinase machine. Oncogene 2015, 34, 4799-4807. [CrossRef]

9. Jang, Y.-J.; Lin, C.-Y.; Ma, S.; Erikson, R.L. Functional studies on the role of the C-terminal domain of mammalian polo-like kinase. Proc. Nat. Acad. Sci. USA 2002, 99, 1984-1989. [CrossRef]

10. Reindl, W.; Yuan, J.; Kraemer, A.; Strebhardt, K.; Berg, T. Inhibition of polo-like kinase 1 by blocking polo-box domain-dependent protein-protein interactions. Chem. Biol. 2008, 15, 459-466. [CrossRef]

11. Reindl, W.; Graeber, M.; Strebhardt, K.; Berg, T. Development of high-throughput assays based on fluorescence polarization for inhibitors of the polo-box domains of polo-like kinases 2 and 3. Anal. Biochem. 2009, 395, 189-194. [CrossRef]

12. Gjertsen, B.T.; Schoffski, P. Discovery and development of the polo-like kinase inhibitor volasertib in cancer therapy. Leukemia 2015, 29, 11-19. [CrossRef]

13. Berg, A.; Berg, T. Inhibitors of the polo-box domain of polo-like kinase 1. ChemBioChem 2016, 17, 650-656. [CrossRef]

14. Yun, S.-M.; Moulaei, T.; Lim, D.; Bang, J.K.; Park, J.-E.; Shenoy, S.R.; Liu, F.; Kang, Y.H.; Liao, C.; Soung, N.-K.; et al. Structural and functional analyses of minimal phosphopeptides targeting the polo-box domain of polo-like kinase 1. Nat. Struct. Mol. Biol. 2009, 16, 876-882. [CrossRef]

15. Liu, F.; Park, J.-E.; Qian, W.-J.; Lim, D.; Graber, M.; Berg, T.; Yaffe, M.B.; Lee, K.S.; Burke, T.R., Jr. Serendipitous alkylation of a Plk1 ligand uncovers a new binding channel. Nat. Chem. Biol. 2011, 7, 595-601. [CrossRef]

16. Liu, F.; Park, J.-E.; Qian, W.-J.; Lim, D.; Scharow, A.; Berg, T.; Yaffe, M.B.; Lee, K.S.; Burke, T.R., Jr. Identification of high affinity polo-like kinase 1 (Plk1) polo-box domain binding peptides using oxime-based diversification. ACS Chem. Biol. 2012, 7, 805-810. [CrossRef]

17. Liu, F.; Park, J.-E.; Qian, W.-J.; Lim, D.; Scharow, A.; Berg, T.; Yaffe, M.B.; Lee, K.S.; Burke, T.R., Jr. Peptoid-peptide hybrid ligands targeting the polo box domain of polo-like kinase 1. ChemBioChem 2012, 13, 1291-1296. [CrossRef]

18. Qian, W.-J.; Park, J.-E.; Grant, R.; Lai, C.C.; Kelley, J.A.; Yaffe, M.B.; Lee, K.S.; Burke, T.R., Jr. Neighbor-directed histidine $\mathrm{N}(\tau)$-alkylation: A route to imidazolium-containing phosphopeptide macrocycles. Pept. Sci. 2015, 104, 663-673. [CrossRef]

19. Hymel, D.; Grant, R.A.; Tsuji, K.; Yaffe, M.B.; Burke, T.R., Jr. Histidine N( $\tau$ )-cyclized macrocycles as a new genre of polo-like kinase 1 polo-box domain-binding inhibitors. Bioorg. Med. Chem. Lett. 2018, 28, 3202-3205. [CrossRef]

20. Sledz, P.; Stubbs, C.J.; Lang, S.; Yang, Y.-Q.; McKenzie, G.J.; Venkitaraman, A.R.; Hyvoenen, M.; Abell, C. From crystal packing to molecular recognition: Prediction and discovery of a binding site on the surface of polo-like kinase 1. Angew. Chem. Int. Ed. Engl. 2011, 50, 4003-4006. [CrossRef]

21. Tan, Y.S.; Śledź, P.; Lang, S.; Stubbs, C.J.; Spring, D.R.; Abell, C.; Best, R.B. Using ligand-mapping simulations to design a ligand selectively trgeting a cryptic surface pocket of polo-like kinase 1. Angew. Chem. Int. Ed. Engl. 2012, 51, 10078-10081. [CrossRef]

22. Śledź, P.; Lang, S.; Stubbs, C.J.; Abell, C. High-throughput interrogation of ligand binding mode using a fluorescence-based assay. Angew. Chem. Int. Ed. Engl. 2012, 51, 7680-7683. [CrossRef]

23. Elia, A.E.; Rellos, P.; Haire, L.F.; Chao, J.W.; Ivins, F.J.; Hoepker, K.; Mohammad, D.; Cantley, L.C.; Smerdon, S.J.; Yaffe, M.B. The molecular basis for phosphodependent substrate targeting and regulation of Plks by the polo-box domain. Cell 2003, 115, 83-95. [CrossRef]

24. Qian, W.-J.; Park, J.-E.; Lee, K.S.; Burke, T.R., Jr. Non-proteinogenic amino acids in the pThr-2 position of a pentamer peptide that confer high binding affinity for the polo box domain (PBD) of polo-like kinase 1 (Plk1). Bioorg. Med. Chem. Lett. 2012, 22, 7306-7308. [CrossRef]

25. Zhao, X.Z.; Hymel, D.; Burke, T.R., Jr. Application of oxime-diversification to optimize ligand interactions within a cryptic pocket of the polo-like kinase 1 polo-box domain. Bioorg. Med. Chem. Lett. 2016, 26, 5009-5012. [CrossRef]

26. Zhao, X.Z.; Hymel, D.; Burke, T.R., Jr. Enhancing polo-like kinase 1 selectivity of polo-box domain-binding peptides. Bioorg. Med. Chem. 2017, 25, 5041-5049. [CrossRef] 
27. Angell, Y.L.; Burgess, K. Peptidomimetics via copper-catalyzed azide-alkyne cycloadditions. Chem. Soc. Rev. 2007, 36, 1674-1689. [CrossRef]

28. Yoo, B.; Shin, S.B.Y.; Huang, M.L.; Kirshenbaum, K. Peptoid macrocycles: Making the rounds with peptidomimetic oligomers. Chem. Eur. J. 2010, 16, 5528-5537. [CrossRef]

29. Kappe, C.O.; Van der Eycken, E. Click chemistry under non-classical reaction conditions. Chem. Soc. Rev. 2010, 39, 1280-1290. [CrossRef]

30. Pedersen, D.S.; Abell, A. 1,2,3-Triazoles in peptidomimetic chemistry. Eur. J. Org. Chem. 2011, 13, $2399-2411$. [CrossRef]

31. Ahmad Fuaad, A.A.; Azmi, F.; Skwarczynski, M.; Toth, I. Peptide conjugation via CuAAC 'click' chemistry. Molecules 2013, 18, 13148-13174. [CrossRef]

32. Das, R.; Majumdar, N.; Lahiri, A. A review on 1,3-dipolar cycloaddition reactions in bioconjugation and it's importance in pharmaceutical chemistry. Int. J. Res. Pharm. Chem. 2014, 4, 467-472. [CrossRef]

33. Fehlhammer, W.P.; Beck, W. Azide chemistry-An inorganic perspective, part II [3+2]-cycloaddition reactions of metal azides and related systems. Z. Anorg. Allg. Chem. 2015, 641, 1599-1678. [CrossRef]

34. Johansson, J.R.; Beke-Somfai, T.; Said Stålsmeden, A.; Kann, N. Ruthenium-catalyzed azide alkyne cycloaddition reaction: Scope, mechanism, and applications. Chem. Rev. 2016, 116, 14726-14768. [CrossRef] [PubMed]

35. Barlow, T.M.A.; Tourwé, D.; Ballet, S. Cyclisation to form small, medium and large rings by use of catalysed and uncatalysed azide-alkyne cycloadditions (AACs). Eur. J. Org. Chem. 2017, 32, 4678-4694. [CrossRef]

36. Buysse, K.; Farard, J.; Nikolaou, A.; Vanderheyden, P.; Vauquelin, G.; Sejer Pedersen, D.; Tourwé, D.; Ballet, S. Amino triazolo diazepines (Ata) as constrained histidine mimics. Org. Lett. 2011, 13, 6468-6471. [CrossRef]

37. Chen, Y.; Li, Z.; Liu, Y.; Lin, T.; Sun, H.; Yang, D.; Jiang, C. Identification of novel and selective non-peptide inhibitors targeting the polo-box domain of polo-like kinase 1. Bioorg. Chem. 2018, 81, 278-288. [CrossRef]

38. Appel, R. Tertiary phosphane/tetrachloromethane, a versatile reagent for chlorination, dehydration, and phosphorus-nitrogen linkage. Angew. Chem. Int. Ed. Engl. 1975, 14, 801-811. [CrossRef]

39. Qian, W.; Liu, F.; Burke, T.R., Jr. Investigation of unanticipated alkylation at the N(pi) position of a histidyl residue under Mitsunobu conditions and synthesis of orthogonally protected histidine analogues. J. Org. Chem. 2011, 76, 8885-8890. [CrossRef]

40. Tornoe, C.W.; Christensen, C.; Meldal, M. Peptidotriazoles on solid phase: $[1,2,3]$-triazoles by regiospecific copper(I)-catalyzed 1,3-dipolar cycloadditions of terminal alkynes to azides. J. Org. Chem. 2002, 67,3057-3064. [CrossRef]

41. Rostovtsev, V.V.; Green, L.G.; Fokin, V.V.; Sharpless, K.B. A stepwise Huisgen cycloaddition process: Copper(I)-catalyzed regioselective "ligation" of azides and terminal alkynes. Angew. Chem. Int. Ed. Engl. 2002, 41, 2596-2599. [CrossRef]

42. Tron, G.C.; Pirali, T.; Billington, R.A.; Canonico, P.L.; Sorba, G.; Genazzani, A.A. Click chemistry reactions in medicinal chemistry: Applications of the 1,3-dipolar cycloaddition between azides and alkynes. Med. Res. Rev. 2008, 28, 278-308. [CrossRef]

43. Zhang, L.; Chen, X.; Xue, P.; Sun, H.H.Y.; Williams, I.D.; Sharpless, K.B.; Fokin, V.V.; Jia, G. Ruthenium-catalyzed cycloaddition of alkynes and organic azides. J. Am. Chem. Soc. 2005, 127, 15998-15999. [CrossRef]

44. Rasmussen, L.K.; Boren, B.C.; Fokin, V.V. Ruthenium-catalyzed cycloaddition of aryl azides and alkynes. Org. Lett. 2007, 9, 5337-5339. [CrossRef]

45. Creary, X.; Anderson, A.; Brophy, C.; Crowell, F.; Funk, Z. Method for assigning structure of 1,2,3-triazoles. J. Org. Chem. 2012, 77, 8756-8761. [CrossRef]

46. Xu, J.; Shen, C.; Wang, T.; Quan, J. Structural basis for the inhibition of polo-like kinase 1. Nat. Struct. Mol. Biol. 2013, 20, 1047-1053. [CrossRef]

47. Fish, P.V.; Ryckmans, T.; Stobie, A.; Wakenhut, F. [4-(Phenoxy)pyridin-3-yl]methylamines: A new class of selective noradrenaline reuptake inhibitors. Bioorg. Med. Chem. Lett. 2008, 18, 1795-1798. [CrossRef]

48. Siebertz, K.D.; Hackenberger, C.P.R. Chemoselective triazole-phosphonamidate conjugates suitable for photorelease. Chem. Commun. 2018, 54, 763-766. [CrossRef]

49. Boren, B.C.; Narayan, S.; Rasmussen, L.K.; Zhang, L.; Zhao, H.; Lin, Z.; Jia, G.; Fokin, V.V. Ruthenium-catalyzed azide-alkyne cycloaddition: Scope and mechanism. J. Am. Chem. Soc. 2008, 130, 8923-8930. [CrossRef] 
50. Hymel, D.; Burke, T.R., Jr. Phosphatase-stable phosphoamino acid mimetics that enhance binding affinities with the polo-box domain of polo-like kinase 1. ChemMedChem 2017, 12, 202-206. [CrossRef]

51. Hanisch, A.; Wehner, A.; Nigg, E.A.; Sillje, H.H.W. Different Plk1 functions show distinct dependencies on polo-Box domain-mediated targeting. Mol. Biol. Cell 2006, 17, 448-459. [CrossRef]

52. Golsteyn, R.M.; Schultz, S.J.; Bartek, J.; Ziemiecki, A.; Ried, T.; Nigg, E.A. Cell cycle analysis and chromosomal localization of human Plk1, a putative homologue of the mitotic kinases Drosophila polo and Saccharomyces cerevisiae Cdc5. J. Cell Sci. 1994, 107, 1509-1517.

Sample Availability: Samples of select peptides may be available from the authors in limited quantities.

(C) 2019 by the authors. Licensee MDPI, Basel, Switzerland. This article is an open access article distributed under the terms and conditions of the Creative Commons Attribution (CC BY) license (http://creativecommons.org/licenses/by/4.0/). 